\title{
Antibacterial Evaluation and Phytochemical Analysis of Selected Medicinal Plants against Some Pathogenic Enteric Bacteria in Gozamin District, Ethiopia
}

\author{
Fentahun $\mathbf{M}^{1}$, Ayele Yilkal $\mathrm{B}^{2 *}$, Amsalu N1, Alemayehu $\mathrm{A}^{3}$ and Amsalu $\mathrm{G}^{1}$ \\ ${ }^{1}$ Department of Biology, Debre Markos University, Ethiopia \\ ${ }^{2}$ Department of Biotechnology, Debre Markos University, Ethiopia \\ ${ }^{3}$ Department of Chemistry, Debre Markos University, Ethiopia
}

\begin{abstract}
Antibacterial activity evaluation and Phytochemical Analysis of aqueous, chloroform, methanol and ethanol crude extracts of thirteen medicinal plants species that were selected based on ethno botanical information on their traditional use were tested for treatment of enteric disease in Gozamin District. The study has been carried out from January 5, 2014 to February 15, 2015. All of these plants were extracted following standard methods (Soaking extraction method and agar-well diffusion) to screen of potential anti-microbial substance. All crude extracts of those medicinal plants were tested against standard reference strains including Escherichia coli, Staphylococcus aureus, Shigella sonnei, Pseudomonas aeruginosa and Salmonella typhimurium. The highest antibacterial activity $(17 \mathrm{~mm})$ was observed from chloroform leaf extract of Eucalyptus globules against $E$. coli and leaf extract of Verbena officinalis $(13.6 \mathrm{~mm})$ extract against Shigella sonnei, followed by methanol leaf extract of Cordia africana $(12.8 \mathrm{~mm})$ against $E$. coli. More over Eucalyptus globules was positive for all bioactive compounds tested except saponins and Verbena officinalis was positive for all bioactive ingredients tested except alkaloids. In general extracts of Eucalyptus globules leaves exhibited the highest potency against $E$. coli and extract Verbena officinalis showed highest potency against Shigella sonnei. Thus, this study confirmed the alternative sources of medicine for pathogenic enteric bacteria tested.
\end{abstract}

Keywords: Enteric disease; Crude extracts; Phytochemical studies

\section{Introduction}

Plants have not only nutritional value but also, in the eyes of the local people, they have medicinal and ritual or magical values [1] Traditional medicinal plants have important contributions in the health care system of local communities as the main source of medicine for the majority of the rural population. These medical systems are heavily dependent on various plant species and plant based products. Since time immemorial, plants have been indispensable sources of both preventive and curative traditional medicine preparations for human beings and livestock [2]. There are more than 35,000 plant species being used in various human cultures around the world for medicinal purpose [3].

According to WHO, over $80 \%$ of the world's population relies upon traditional plant-based systems of medicines to provide them with primary healthcare [4]. Fransworth and Soejarto [5] also echoed the same with their estimation that $70-80 \%$ of people worldwide rely chiefly on traditional, largely herbal medicine to meet their primary healthcare needs. It is further indicated that herbal medicine is still the mainstay of about $75-80 \%$ of the world population, mainly in the developing countries, for primary healthcare. This is primarily because of the general belief that herbal drugs are without any side effects besides being cheap and locally available [6].

Researchers are still searching for the potential antimicrobial substances from medicinal plants due to the increasing failure of chemotherapeutics and antibiotic resistance exhibited by pathogenic microorganisms [7]. It is important to note that microbial diseases continued to be major threats to the world regardless of efforts and progress in developing modern medicine [8]. The impact of microbial diseases is especially important in developing countries such as Ethiopia where there is limited access to modern drugs and prices are mostly unaffordable when the latter are available [9]. A focused phytochemical screening, backed by ethnomedicinal data, often leads to the discovery of new lead compounds that can play a role in the global efforts against pathogens [10].

The emergence and spread of multidrug-resistant (MDR) enteric bacterial pathogens have substantially threatened the current antibacterial therapy [11]. MDR enteric bacterial infections often lead to increased mortality, longer length of stays in hospitals, and higher cost of treatment and care [11] and [12]. The therapeutic alternatives for these pathogens are extremely limited and physicians are forced to use expensive or previously discarded drugs, such as colistin, that are associated with significant side effect to the patients' health [12]. Therefore, it is necessary to search other potential alternatives that can be effective in the treatment of these problematic bacterial infections. In addition to this problem, antibiotics are sometimes associated with adverse effects on the host including hypersensitivity, immunesuppression and allergic reactions. This situation forced scientists to search for new antimicrobial substances.

In Ethiopia, medicinal plants have been used as traditional medicine to treat different human and livestock ailments by the local people from time immemorial. Ethiopian plants have shown very effective

*Corresponding author: Yilkal Bezie, Department of Biotechnology, Debre Markos University, Ethiopia, Tel: 09924314799; E-mail: yilkalb@gmail.com

Received: October 04, 2017; Accepted October 20, 2017; Published October 27, 2017

Citation: Fentahun M, Ayele Yilkal B, Amsalu N, Alemayehu A, Amsalu G (2017) Antibacterial Evaluation and Phytochemical Analysis of Selected Medicinal Plants against Some Pathogenic Enteric Bacteria in Gozamin District, Ethiopia. J Pharmacovigil 5: 244. doi:10.4172/2329-6887.1000244

Copyright: (c 2017 Fentahun M, et al. This is an open-access article distributed under the terms of the Creative Commons Attribution License, which permits unrestricted use, distribution, and reproduction in any medium, provided the original author and source are credited. 
Citation: Fentahun M, Ayele Yilkal B, Amsalu N, Alemayehu A, Amsalu G (2017) Antibacterial Evaluation and Phytochemical Analysis of Selected Medicinal Plants against Some Pathogenic Enteric Bacteria in Gozamin District, Ethiopia. J Pharmacovigil 5: 244. doi:10.4172/23296887.1000244

Page 2 of 6

medicinal value for the treatment of virus diseases. Medicinal plants and knowledge of their use provide a vital contribution to human and livestock healthcare in the country at large [13]. Due to its long period of practice and existence, traditional medicine has become an integral part of the culture of Ethiopian people. There is a large magnitude of use and interest in medicinal plants in Ethiopia due to acceptability, accessibility and biomedical benefits [14]. The same is true to people living in gozamen district and hence they are highly dependent on medicinal plants for their primary healthcare.

Antimicrobial evaluation of studies is often significant in revealing locally available and important plant species especially for the discovery of crude drugs. In Ethiopia, has a long history of traditional healthcare system, however studies conducted on the traditional medicinal plants are limited when compared with the multiethnic, cultural and flora diversity [15]. Hence this study would contribute to fill the existing gap in determining the antimicrobial effect of selected traditional plants and to declare bioactive compounds found in each evaluated medicinal plants in Gozamin District.

Therefore the study was necessitated to evaluate the antimicrobial effect of some commonly used potential medicinal plants and its phytochemical test in Gozamen District. This could attribute to the effective utilization of natural resources in the locality there by transforming the traditional knowledge to scientific way of utilization of those medicinal plants to be used as raw material to pharmaceutical industries, as well as to conserve rare or highly demanded plant species in traditional medicine.

\section{Objectives of the Study}

\section{General objective}

The main objective of this research was evaluation on antibacterial activity of some selected traditionally used medicinal plants against pathogenic enteric bacteria and determination of the bioactive compounds.

\section{Specific objectives}

- To evaluate the antibacterial activity of medicinal plants on enteric bacteria pathogens

- To identify the class of most common phytochemicals present in the selected medicinal plants

- To estimate the metabolic activity of the plant extract

\section{Materials and Methods}

\section{Study area}

Gozamin district is one of the 18 districts in east gojjam zone and 151 districts in amahara national regional state. The relative location of the district is $300 \mathrm{~km}$ away from the capital city of the country, addis ababa and $260 \mathrm{~km}$ from bahir dar, the regional capital city. This district is found almost mid-way from addis ababa to bahir dar. The district is bounded by senan district in the north, basoleben district and oromiya national regional state in the south, aneded and debaytilatgen district to the east and machakle and debere elias district in the west [16]. Medicinal plants were collected in kebeles of gozamin district. The antimicrobial evaluation was made in biology department microbiological laboratory and the phytochemical analysis was made in chemistry department analytical chemistry laboratory of debre markos university.

\section{Plant materials}

Plant specimens were collected from gozamin district between 25 June and 26 September 2009, 9 January-20 February 2010, 22 May-27 August 2010 and 14 Febraury-7 May 2011.

\section{Selection of medicinal plants}

Thirteen medicinal plant species with relatively high informant consensus value for treating infectious diseases in the study area were selected for further antimicrobial activity study [17]. The thirteen plants were prioritized as common important for the treatment of gastrointestinal disease in the study area. Local use reports of candidate medicinal plants from the study area were also thoroughly compared for related ethnomedicinal use reports from other parts of the country

These plants are (E. globules, Rhamnus prinoides, Verbena officinalis, Otostigia integrifolia, Brucea antidisenterica, Sida schimperiana, Carica papaya, Phytolacca dodecandra, Cordia Africana, Vernonia amygdalina, Foeniculum vulgare, Withania somnifera, Cymbopogans martini).

\section{Extraction of plant material via maceration (Soaking)}

Each plant samples were prepared following Panthi and Chaudhary, (2006) method of extraction; clean dry (dried under shade) plant samples were collected in cotton bags. The material was grinded using a grinder (blender). Each selected medicinal plant $40 \mathrm{~g}$ of sample was immersed in each of three conical flask containing $400 \mathrm{ml}$ ethanol, 400 $\mathrm{ml}$ methanol and $400 \mathrm{ml}$ chloroform solvent. The soaked samples were stayed for 72 hours with shaking of the extracts in the intermediate time. After 3 days the extract was filtered by using standard filter paper what man number 1 . The collected extract was further separated by rotary evaporator at $40^{\circ} \mathrm{C}$ reduced temperature. Finally the crude extract was placed in desiccators containing $\mathrm{Cacl}_{2}$ The dried extract was put in refrigerator for further uses. The dry weight of the extracts were obtained by allowing the solvent to evaporate and also used to determine concentration in $\mathrm{mg} / \mathrm{ml}$.

\section{Culture media used}

Muller Hinton Agar (Oxoid, UK), Nutrient Broth (Himedia, India) and Nutrient Agar (Science Company, UK) were used during the study. Muller Hinton agar was used for the antimicrobial tests and Nutrient Agar was also used for routine stock cultures and sub culturing.

\section{Test microorganisms and microbial culture}

Four gram negative bacteria; (Escherichia coli ATCC 25722, Salmonella typhimurieum ATCC 13311, Shigella sonnei ATCC259131 and Pseudomonas aeriginosa ATCC27853) and one Gram positive bacteria (Staphylococcus aureus ATCC 25903) known to cause food borne bacterial infection were used to evaluate the antimicrobial activity of crude extracts of medicinal plants. The test microorganisms were obtained from Ethiopian Health and Nutrition Research Institute (EHNRI) clinical bacteriology laboratory, addis ababa. The Bacterial strains were reactivated by sub culturing on nutrient broth at $37^{\circ} \mathrm{C}$ and maintained on nutrient agar slant at $4^{\circ} \mathrm{C}$ for further activity.

\section{Standardization of inocula}

The 0.5 McFarland turbidity standard was prepared by adding $0.5 \mathrm{ml}$ of a $1.175 \%(\mathrm{wt} / \mathrm{vol})$ barium chloride dehydrate $\left(\mathrm{BaCl}_{2} 2 \mathrm{H}_{2} 0\right)$ solution to $99.5 \mathrm{ml}$ of $1 \%$ ( $\mathrm{vol} / \mathrm{vol}$ ) sulfuric acid $\left(\mathrm{H}_{2} \mathrm{SO}_{4}\right)$. This mix was considered to be equivalent to cell density of 1 to $2 \times 10^{8} \mathrm{cfu} / \mathrm{ml}$ [18]. The turbidity standard is then aliquoted into test tubes identical to 
Citation: Fentahun M, Ayele Yilkal B, Amsalu N, Alemayehu A, Amsalu G (2017) Antibacterial Evaluation and Phytochemical Analysis of Selected Medicinal Plants against Some Pathogenic Enteric Bacteria in Gozamin District, Ethiopia. J Pharmacovigil 5: 244. doi:10.4172/23296887.1000244

Page 3 of 6

those used to prepare the inoculums suspension. McFarland turbidity standard tubes were Seal with Parafilm, to prevent evaporation. Barium sulfate turbidity was compared with identical tubes containing inocula $0.85 \% \mathrm{NaCl}$ saline solution.

\section{Agar disk diffusion assay}

Agar disk diffusion method was used to evaluate the antibacterial activities of extracts of medicinal plants according to [19]. The 24 hours plate cultures of $0.5 \mathrm{Mc}$ Farland standard ( 1 to $2 \times 10^{8} \mathrm{CFU} \mathrm{ml}-1$ ) bacterial suspensions were uniformly spread on Mueller-Hinton agar plate (Oxoid) to form lawn cultures. The chloroform, methanol and ethanol crude extracts were dissolved in tween -20 solvent. The stock solutions were prepared at amount of $100 \mathrm{mg} / \mathrm{ml}$ for each solvent extracts. The blotting paper discs $(6 \mathrm{~mm}$ diameter $)$ were soaked in various dilute solvent extracts, and dried for 5 minutes to avoid flow of extracts in the test media. Antibacterial activity of potential plant extract against bacterial pathogens by disc diffusion technique were identified after incubation for $24 \mathrm{~h}$. at $37^{\circ} \mathrm{C}$, and the result was obtaind by measured the zone of inhibition of growth in $\mathrm{mm}$. Standard antibiotic disc (Ampcilin $30 \mu \mathrm{g}$ ) were used as positive control.

\section{Phyto-chemical analysis}

Eight traditional plants which were found positive antimicrobial effect were further tested for the most common Phyto-chemicals (secondary metabolites) such as alkaloids, glycosides, flavonoids, tannins, saponins and phenolics present in powdered forms were analyzed following methods described in Trease and Evans [20], Ayoola GA et al. [21] Rasool R et al. [22].

\section{Test for tannins}

Half gram of the powdered plant materials were boiled in $10 \mathrm{ml}$ of distilled water in a $100 \mathrm{ml}$ beaker sized and then filtered; few drops of $0.1 \%$ ferric chloride $\left(\mathrm{FeCl}_{3}\right)$ were added. Formation of brownish green or a blue-black coloration indicates the presence of tannins [21].

\section{Test for alkaloids}

From about $0.5 \mathrm{~g}$ of powdered plant materials boiled in $10 \mathrm{ml}$ of prepared acid alcohol and filtered, about $5 \mathrm{ml}$ of the filtrate was taken and $2 \mathrm{ml}$ of dilute ammonia added. Then $5 \mathrm{ml}$ of chloroform was also added and shaken gently. The chloroform layer was extracted with 10 $\mathrm{ml}$ of acetic acid. Formation of a cream with Mayer's reagent confirms the presence of alkaloids [21].

\section{Test for saponins}

To $0.5 \mathrm{~g}$ of powdered plant materials in a test tube, $5 \mathrm{ml}$ of distilled water was added and the mixture was vigorously shaken. Formation of a froth Persistent for 30 min confirms the presence of saponins [21].

\section{Test for flavonoids}

To a portion of an aqueous filtrate of the powdered plant materials about $5 \mathrm{ml}$ of dilute ammonia solution was added. Concentrated sulphuric acid $(1 \mathrm{ml})$ addition and yellow colorations that disappeared on standing indicated the presence of flavonoids [21].

\section{Test for cardiac glycosides}

To $2 \mathrm{ml}$ alcoholic filtrate plant materials, $1 \mathrm{ml}$ glacial acetic acid and 1-2 drops of $\mathrm{FeCl}_{3}$ was added and $1 \mathrm{ml}$ of concentrated $\mathrm{H}_{2} \mathrm{SO}_{4}$ followed. Appearance of brown ring at the interface indicated presence of cardiac glycosides. A violet ring also appeared below the brown ring confirm positive for cardiac glycosides [20].

\section{Test for phenolics}

To $2 \mathrm{ml}$ of alcoholic or aqueous plant filtrate, $1 \mathrm{ml}$ of $1 \%$ ferric chloride solution was added. After a minute appearance of blue or green color indicates presence of phenols [21].

\section{Data analysis}

Results obtained in this study were expressed as mean inhibition zone $(\mathrm{mm}) \pm$ S.D of three replicates. The mean and the standard deviation of each herbal extract were used to compute the calculated $\mathrm{t}$-value.

The phytochemical tests were recorded as + (plus sign) for positive results for the tested bioactive compounds and - (minus sign) for the negative results for the tested result.

\section{Results}

\section{Antibacterial activity of medicinal plants extracted by soaking method}

The results showed that the among thirteen selected commonly used traditional medicinalplants only eight medicinal plant species, namely: E. globules, Otostegia integrifolia, Verbena officinalis, Cordia Africana, Foeniculum vulgare, Withania somnifera, Phytolacca dodecandra and Brucea antidisenterica were displayed positive effect on standard reference of enteric pathogenic bacterial strains $E$. coli (ATCC25722), S. aureus (ATCC25903), S. sonnei (ATCC259131), P. aeriginosa (ATCC27853)and S. typhimerium (ATCC13311).

Each medicinal plant extracted by chloroform, methanol and ethanol solvents showed a highly significant difference on inhibition zone diameters against the test of strains which ranged between $4 \mathrm{~mm}$ and $17 \mathrm{~mm}$. The highest antibacterial activity $(17 \mathrm{~mm})$ was observed from chloroform leaf extract of E. Globules against E. coli (Figure 1A) and chloroform leaf extract extract of Verbena officinalis extract $(13.6 \mathrm{~mm})$ against Shigella sonnei, followed by methanol leaf extract of Cordia Africana $(12.8 \mathrm{~mm})$ against $E$. coli. From this study chloroform leaf extract of Brucea antidisenterica showed antimicrobial activity (11.0 $\mathrm{mm}$ ) against Pseudomonas aeriginosa

Among all plant extracts analyzed minimum antibacterial activity was exhibited by the chloroform leaf extract of Brucea antidisenterica against $S$. typhimerium $(4.3 \mathrm{~mm})$, Phytolacca dodecandra against $P$. aeriginosa $(4.9 \mathrm{~mm})$, Foeniculum vulgare against $S$. typhimerium (4.7 $\mathrm{mm}$ ) (Figure $1 \mathrm{~B}$ ) and one or more negative activity was observed from all leaf extract example all leaf extract Foeniculum vulgare except chloroform extract, all leaf Phytolacca dodecandra except chloroform extract against $P$. aeriginosa and all chloroform leaf extract Cordia Africana except methanol and ethanol extracts showed zero inhibition zones (Table 1).

\section{Phytochemical screening of selected medicinal plants}

Our finding confirmed that all extracted plants contain different secondary metabolites such as alkaloids, cardiac glycosides, flavonoids, saponins, tannins and phenols (Table 2).

\section{Discussion}

\section{Evaluation of antibacterial activities of crude extracts}

The highest antibacterial activity $(17 \mathrm{~mm})$ was observed from chloroform leaf extract of E. globules against E. coli and chloroform leaf extract of Cordia Africana $(12.8 \mathrm{~mm})$ against E. coli and chloroform 
Citation: Fentahun M, Ayele Yilkal B, Amsalu N, Alemayehu A, Amsalu G (2017) Antibacterial Evaluation and Phytochemical Analysis of Selected Medicinal Plants against Some Pathogenic Enteric Bacteria in Gozamin District, Ethiopia. J Pharmacovigil 5: 244. doi:10.4172/23296887.1000244

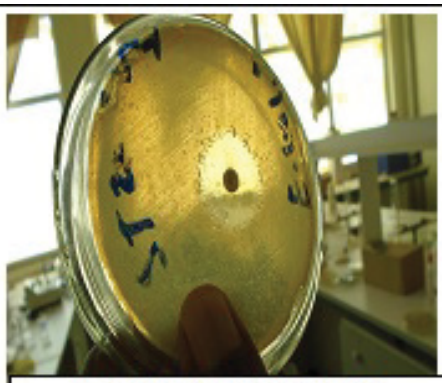

A. Chloroform Extract of Eucalyptus globules

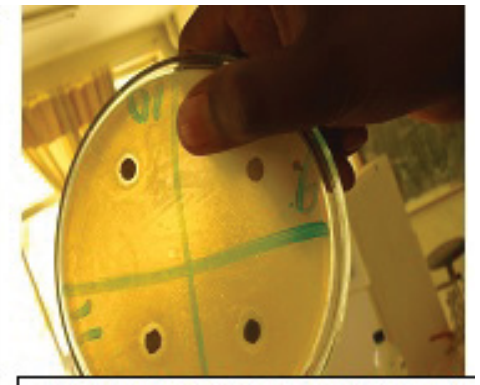

B. Chloroform Extract of Foeniculum vulgare Against S. sonni.

Figure 1: Zone of inhibition chloroform extract of eucalyptus globules against E.coli and chloroform extract of Foeniculum vulgare against S. sonni.

\begin{tabular}{|c|c|c|c|c|c|c|}
\hline \multirow[b]{2}{*}{ Scientific names } & \multirow[b]{2}{*}{ Solvent extracts } & \multicolumn{5}{|c|}{ Bacterial strains } \\
\hline & & $\begin{array}{c}\text { Staphylococcus aureus } \\
\text { (ATCC25903) }\end{array}$ & $\begin{array}{c}\text { Salmonella } \\
\text { typhimurium } \\
\text { (ATCC13311) }\end{array}$ & $\begin{array}{c}\text { Pseudomonas } \\
\text { aeriginosa } \\
\text { (ATCC27853) }\end{array}$ & $\begin{array}{l}\text { Shigella sonnei } \\
\text { ATCC259131 }\end{array}$ & $\begin{array}{c}\text { Escherichia coli (ATCC } \\
\text { 25722) }\end{array}$ \\
\hline \multirow{3}{*}{ Eucalyptus globules Labill. } & Ethanol & $11.8 \pm 1.04$ & $11 \pm 1.0$ & NA & $8 \pm 0.5$ & $16.5 \pm 0.5$ \\
\hline & Methanol & $10.3 \pm 1.52$ & $8.8 \pm 0.28$ & NA & $8.3 \pm 1.15$ & $16.6 \pm 3.5$ \\
\hline & Chloroform & $13 \pm 2.6$ & $7.5 \pm 0.86$ & NA & $8 \pm 1$ & $17 \pm 1.7$ \\
\hline \multirow{3}{*}{ Verbena officinalis L. } & Ethanol & $10.5 \pm 1.28$ & NA & NA & $11.8 \pm 1.4$ & $12.6 \pm 0.57$ \\
\hline & Methanol & $8.3 \pm 0.57$ & NA & NA & $13.1 \pm 1.04$ & $11.8 \pm 0.28$ \\
\hline & Chloroform & $9 \pm 2$ & NA & NA & $13.6 \pm 0.57$ & $12.3 \pm 0.57$ \\
\hline \multirow{3}{*}{ Otostegia integrifolia Benth. } & Ethanol & $6.3 \pm 1.15$ & NA & NA & $7 \pm 1$ & NA \\
\hline & Methanol & $8.6 \pm 1.04$ & NA & NA & $6.1 \pm 0.28$ & NA \\
\hline & Chloroform & $9.1 \pm 0.28$ & NA & NA & $9.3 \pm 1.5$ & NA \\
\hline \multirow{3}{*}{$\begin{array}{c}\text { Brucea antidysentericaSwiss } \\
\text { Chard. }\end{array}$} & Ethanol & NA & NA & NA & NA & NA \\
\hline & Methanol & NA & NA & NA & NA & NA \\
\hline & Chloroform & $7 \pm 1.0$ & $4.3 \pm 0.57$ & $11 \pm 0.0$ & $5.5 \pm 0.5$ & NA \\
\hline \multirow{3}{*}{$\begin{array}{c}\text { Phytolacca dodecandra } \\
\text { L'Herit. }\end{array}$} & Ethanol & NA & NA & NA & NA & NA \\
\hline & Methanol & NA & NA & NA & NA & NA \\
\hline & Chloroform & NA & NA & $4.9 \pm 1.36$ & NA & NA \\
\hline \multirow{3}{*}{ Cordia africana Lame. } & Ethanol & $7.3 \pm 1.15$ & $9.1 \pm 1.04$ & $5 \pm 1.0$ & $8 \pm 0.0$ & $11.6 \pm 0.57$ \\
\hline & Methanol & $5.8 \pm 0.76$ & $8.5 \pm 0.5$ & $4 \pm 1.0$ & $6.8 \pm 0.76$ & $12.8 \pm 1.25$ \\
\hline & Chloroform & NA & NA & NA & NA & NA \\
\hline \multirow{3}{*}{ Foeniculum vulgare Miller. } & Ethanol & NA & NA & NA & NA & NA \\
\hline & Methanol & NA & NA & NA & NA & NA \\
\hline & Chloroform & $7 \pm 0.0$ & $4.7 \pm 0.75$ & $5.8 \pm 0.28$ & $5.8 \pm 1.04$ & $8.3 \pm 0.57$ \\
\hline \multirow{3}{*}{$\begin{array}{c}\text { Withania somnifera (L.) } \\
\text { Dunal in DC. }\end{array}$} & Ethanol & $8.1 \pm 1.15$ & NA & NA & $6.4 \pm 0.85$ & NA \\
\hline & Methanol & $8.8 \pm 1.4$ & NA & NA & $5.6 \pm 0.76$ & NA \\
\hline & Chloroform & $8.8 \pm 1.4$ & NA & NA & $9.8 \pm 0.28$ & NA \\
\hline Ampicilin & - & $22.8 \pm 0.2$ & $21.4 \pm 0.5$ & $23 \pm 0.0$ & $24.3 \pm 0.3$ & $20.1 \pm 0.45$ \\
\hline
\end{tabular}

NA-Not have Activities. Values are mean inhibition zone $(\mathrm{mm}) \pm$ S.D of the replicates and the superscripted similar letters show absence of statistical significance $(P<0.05)$ among the values. Statistically significance considered at $p<0.05$.

Table 1: Antibacterial activities of selected medicinal plants extracted by soaking method (conc. $100 \mathrm{mg} / \mathrm{ml}$ ).

\begin{tabular}{|c|c|c|c|c|c|c|c|c|}
\hline \multirow[b]{2}{*}{ Tests } & \multicolumn{8}{|c|}{ Name of Medicinal Plants } \\
\hline & $\begin{array}{l}\text { Eucalyptus } \\
\text { globules }\end{array}$ & $\begin{array}{l}\text { Withania } \\
\text { somnifera }\end{array}$ & $\begin{array}{l}\text { Phytolacca } \\
\text { dodecandra }\end{array}$ & $\begin{array}{c}\text { Brucea } \\
\text { antidisenterica }\end{array}$ & $\begin{array}{c}\text { Otostegia } \\
\text { integrifolia }\end{array}$ & $\begin{array}{l}\text { Verbena } \\
\text { officinalis }\end{array}$ & $\begin{array}{c}\text { Cordia } \\
\text { Africana }\end{array}$ & $\begin{array}{c}\text { Foeniculum } \\
\text { vulgare }\end{array}$ \\
\hline Alkaloids & + & + & + & - & + & - & - & - \\
\hline Tannins & + & - & - & \pm & + & + & + & - \\
\hline Saponins & - & - & + & _- & - & + & + & + \\
\hline Flavonds & + & + & + & + & + & + & - & + \\
\hline $\begin{array}{c}\text { Cardiac } \\
\text { Glycosides }\end{array}$ & + & + & - & + & - & \pm & - & + \\
\hline Phenols & + & + & + & - & - & + & - & \pm \\
\hline
\end{tabular}

Table 2: Phytochemical constituents of the selected medicinal plants. 
Citation: Fentahun M, Ayele Yilkal B, Amsalu N, Alemayehu A, Amsalu G (2017) Antibacterial Evaluation and Phytochemical Analysis of Selected Medicinal Plants against Some Pathogenic Enteric Bacteria in Gozamin District, Ethiopia. J Pharmacovigil 5: 244. doi:10.4172/23296887.1000244

leaf extract of Verbena officinalis $(13.6 \mathrm{~mm})$ against $S$. sonnei. Therefore, this result indicated that chloroform extracts of E. globules, $V$. officinalis and W. somnifera showed more promising activity against tested strains than other plant extracts. This suggests that the extract of this plant has a broad spectrum of antibacterial activities. The result of this study in line with the finding of previous studies reported by [23-25]. However, these antibacterial activities were observed to be significantly lower than that of ampicillin, the standard antibacterial drug used as positive control in this study. This could be due to the fact that the sample extracts used in the test were crude preparation which may not necessarily contain enough of the active chemical. Further purification and fractionation thus needed to yield more isolated bioactive compounds [26].

Otostegia integrifolia and Withania somnifera plant extracts showed negative effect on Gram-negative (S. typhimurium, P. aeriginosa and E. coli) but positive effect on Gram-positive bacterium (S. aureus). However, several previous findings Branter A et al. [27], Nostro et al. [28], Ojala et al. [29] and Velu and Baskaran, [24] reported that Gramnegative bacteria were susceptible to plant extracts when compared to Gram-positive bacteria. The resistance of Gram-negative bacteria towards antibacterial substances is related to lipopolysaccharides in their outer membrane [30] and [31]. This is controversial with the obtained results since most of the extracts showed prominent activity against gram-negative bacteria. Therefore, chloroform extracts of $E$. globules, $V$. officinalis and $C$. Africana which exhibited the highest inhibitory effects against gram-negative bacteria can be developed for the use in drugs industry.

Extraction of antimicrobial metabolites from the selected plant species by chloroform was observed to be more effective methods than ethanol and methanol solvents. For example, while chloroform extracts of Foeniculum vulgare inhibited all five tests of strains but ethanol and methanol extracts inhibited none of one strains. Thus, the efficacy of plant extracts evaluated as antimicrobial agents was dependent on the solvent of extraction. Alzoreky and Nakahara [32] reported that, chloroform was proved to be good solvents in extracting inhibitory substances from medicinal plants. In contrast, Cowan [33] found that methanol was more efficient than acetone in extracting photochemical from plant materials. In accordance with these dissimilar findings, the results of the current study revealed that the solvent type is not the only factor that should be taken in consideration during extraction of plant constituents but also the plant species as well as the test microorganism played an important role in the antimicrobial efficacy.

The test strains exhibited slight or no susceptibility to extracts of $P$. dodecandra, B. antidisenterica and $F$. vulgare but antibacterial activities of chloroform extract which revealed a broad spectrum activity against the test pathogenic microorganisms except $P$. dodecandra extracts. This finding is in disagreement with [34] and [35].

\section{Preliminary phytochemical screening of the selected medicinal plants}

The finding showed that E. globules and Verbena officinalis plant leave had all test compounds except Saponins and Alkaloids respectively. This correlated with the finding of previous studies that reported the presence of antimicrobial substances within the leaves of the plant as described by Saxena $\mathrm{R}$ et al. [36]. According to the report of Ali and Blunden [37] the inclusiveness of all these compounds has contributed to its effective activity against the test strains compared with other plants. This suggests that the extract of this plant has a broad spectrum of antibacterial activities.
According to Saxena R et al. [36], E. globules has essential compounds like, Alkaloids cardiac glycosides, flavonoids, tannins and phenols. To the contrary Obiorah S et al. [38] reported the absence of cardiac glycosides in the leaves of E. globules. Our results indicated Withania somnifera leaf contains Alkaloids, cardiac glycosides, flavonoids and phenols but other reports by Velu and Baskaran [24] indicated the absence of flavonoids in the leave of Withania somnifera. The differences in the reports of many of the study could be due to the difference in time of plant collection, climate, methods of extraction used and other factors.

\section{Conclusions and Recommendations}

Based on the results obtained in this study, all the extracts showed varying degrees of antimicrobial activity against the test strains. However, the activities varied based on the solvents used for extraction. This in vitro study demonstrated that some of the extracts can be as effective as modern medicine to combat the test of the strains. E. globules, Otostegia integrifolia, Verbena officinalis, Cordia africana, Foeniculum vulgare, Withania somnifera, Phytolacca dodecandra and Brucea antidisenterica have antimicrobial activity than other plants extracts to against the tested standard strains. According to results of this study, it can be concluded E. globules, V. officinalis, and $W$. somnifera leaf extract showed broad spectrum of antibacterial activity as evidenced by high zone of inhibition against the test standard strains. These results provide evidence that some of the secondary metabolites present in the studied medicinal plants confirmed as they contained multiple bio compounds which might have synergetic impact on inhibition of pathogenic microbes tested. The finding of this study also indicated that instead of using crude extracts for antimicrobial activity it could be imperative isolating bioactive compounds in its purest form and used for new drug development programs. Therefore, the authors recommend further studies to be done on isolated compounds and fractions of the plant for antimicrobial activity and toxicological screening. Moreover, in-vivo studies should also be conducted in order to confirm the safety and efficacy of this plant's secondary metabolites.

\section{Acknowledgement}

First and for most we would like to appreciate debre markos university since granting the whole expense of this research. We also would like to thank biology and chemistry departments since they let us to use the laboratory set ups to carry out our experimental work. We would like to extend our appreciation to ethiopian health and nutrition research institute clinical bacteriology department for their kind donation of standard bacterial strains for antimicrobial evaluation. Finally, we would like to express our thanks to yohanis mulugeta in identifying and giving scientific names to the collected medicinal plants.

\section{Competing Interests}

The authors declare that they have no competing interests.

\section{References}

1. Abbink J (1995) Medicinal and ritual plants of the ethiopian southwest: an account of recent research. Indigenous Knowledge and Development Monitor 3: 6-8.

2. Dery BB, Otsyina R, Ngatigwa C (1999) Indigenous knowledge of medicinal trees and setting priorities for their domestication in shinyanga rejoin, tanzania. International center for research in agroforestry, nairobi. Cambridge university press, Britain.

3. Philip K, Abd Malek SN, Sani W, Shin SK, Kumar S, et al. (2009) Antimicrobia Activity of Some Medicinal Plants from Malaysia. Am J App Sci 6: 1613-1617.

4. WHO (2000) Western pacific region. a report of the consultation meeting on traditional and modern medicine: harmonizing the two approaches, 22-26 November 1999, Beijing, China.

5. Farnsworth NR, Akerele O, Heywood V, Soejarto DD (1991) Global Importance of Medicinal Plants. In: Conservation of medicinal plants. (eds. Akerele O Heywood V, Synge H). Cambridge Univ. Press, Cambridge, UK 25-51. 
Citation: Fentahun M, Ayele Yilkal B, Amsalu N, Alemayehu A, Amsalu G (2017) Antibacterial Evaluation and Phytochemical Analysis of Selected Medicinal Plants against Some Pathogenic Enteric Bacteria in Gozamin District, Ethiopia. J Pharmacovigil 5: 244. doi:10.4172/23296887.1000244

6. Gupta LM, Raina R (1998) Side effects of some medicinal plants. Current Science 75: 897-900

7. Parekh J, Chanda SV (2007) In Vitro antimicrobial activity and phytochemical analysis of some indian medicinal plants turk. J Biol 31: 53-58.

8. Cos P, Vlietinck AJ, Vanden Berghe D, Maes L (2006) Anti-infective potentia of natural products: How to develop a stronger in vitro 'proof-of-concept'. J Ethnopharmacol 106: 290-292.

9. Savithramma N, Ankanna S, Linga RM, Saradvathi J (2012) Studies on antimicrobial efficacy of medicinal tuberous shrub Talinum cuneifolium. J Environ Biol 33: 775-780.

10. Ermias L, Rondevaldova J, Bernaskova E, Cepkova J, Zemede Asfaw, et al. (2014) Antimicrobial activity of traditional medicinal plants from ankober district, north shewa zone, amhara region, ethiopia. Pharm Biol Early on line: 1-7.

11. Giamarellou H (2010) Multidrug-resistant Gram-negative bacteria: how to treat and for how long. Int J Antimicrob Agents 36: 50-54.

12. Boucher HW, Talbor GH, Bradley JS, Edwards JE, Gilbert D, et al. (2009) Bad bugs, no drugs: no ESKAPE! An update from the Infectious Diseases Society of America. Clin Infect Dis 48: 1-12.

13. Endashaw B (2007) Study on Actual Situation of Medicinal Plants in Ethiopia. Prepared for Japan Association for International Collaboration of Agriculture and Forestry. Addis Ababa, Ethiopia.

14. Gidey Y (2010) Ethno botanical Study of Medicinal Plants in and Around Alamata, Southern Tigray, Northern Ethiopia. Curr Res J Biol Sci 2: 338-344.

15. Fisseha M, Sebsebe D, Tilahun T (2009) An ethnobotanical study of medicinal plants in Wonago Woreda, SNNPR, Ethiopia. J Ethnobiol Ethnomed 5: 28.

16. GWAO (2014) Gozamen Distict Agricultural Office, Debre Markos.

17. Trotter RT, Logan MH (1986) Informants consensus: a new approach for identifying potentially effective medicinal plants. In Plants in Indigenous Medicine and Diet: Behavioral Approaches 91-112.

18. Lalitha MK (2004) Manual of Antimicrobial Susceptibility Testing. Christian Medical College; Vellore, Tamil Nadu. 1-47.

19. Tambekar DH, Khante BS, Panzade BK, Dahikar SB, Banginwar YS (2008) Evaluation of phytochemical and antibacterial potential of helicteres isora I. fruits against enteric bacterial pathogens. Afr J Tradit Complement Altern Med 5: $290-293$.

20. Trease GE, Evans WC (1989) Pharmacognsy. 11th (edn). Brailliar Tiridel Can. Macmillian publishers.

21. Ayoola GA, Coker HAB, Adesegun SA, Adepoju-Bello AA, Obaweya K, et al (2008) Phytochemical screening and antioxidant activities of some selected medicinal plants used for malaria therapy in southwestern nigeria. Trop $J$ Pharm Res 7: 1019-1024.

22. Rasool R, Bashir AG, Seema A, Azra NK, Akbar M (2010) Phytochemical Screening of Prunella Vulgaris L.-An Important Medicinal Plant of Kashmir. Pak J Pharm Sci 23: 399-402.
23. Pranay J, Shekhar N, Gaurav K (2010) Antimicrobial activity and phytochemical analysis of eucalyptus tereticornis bark and leaf methanolic extracts. Int $\mathrm{J}$ Pharm Sci Rev Res 4: 126-128.

24. Velu S, C Baskaran (2012) Phytochemical analysis and in-vitro antimicrobia activity of Withania somnifera (Ashwagandha). J Nat Prod Plant Resour 2 711-716.

25. Berhan M, Jemal MY, Belayneh G (2014) In-vitro antibacterial activity and phytochemical analysis of leaf extract of verbena officinalis. Int J Pharm 1 : 774-779.

26. Fabry W, Okemo PO, Ansorg R (1998) Antibacterial activity of East African medicinal plants. J Ethnopharmacol 60: 79-84.

27. Branter A, Male Z, Pepelinfak S, Atolic A (1996) Antimicrobial activity of Paliurus spina. Chrisfi mill. (Christ-thorn). J Ethnopharmacy 52: 119-122.

28. Nostro A, Germano MP, D'Angelo V, Marino A, Cannatelli MA (2000) Extraction methods and bioautography for evaluation of medicinal plant antimicrobial activity. Lett Applied Microbiol 30: 379-384.

29. Ojala T, Remes S, Haansuu P, Vuorela H, Hiltunen R, et al. (2000) Antimicrobia activity of some coumarin containing herbal plants growing in finland. $J$ Ethnopharmacol 73: 299-305

30. Sawer IK, Berry MI, Ford JL (1997) Effect of medium composition, agitation and presence of EDTA on the antimicrobial activity of cryptolepine. Lett Applied Microbiol 25: 207-211.

31. Gao Y, van Belkum MJ, Stiles ME (1999) The outer membrane of Gramnegative bacteria inhibits antibacterial activity of Brochocin C. Applied Environ Microbiol 65: 4329-4333.

32. Alzoreky NS, Nakahara K (2003) Antibacterial activity of extracts from some edible plants commonly consumed in asia. Int J Food Microbiol 80: 223-230.

33. Cowan MM (1999) Plant products as antimicrobial agents. Clin Microbiol Rev 12: $564-582$.

34. Irene A, Ogutu D, Baraza L, Charles M, Christine B (2012) Phytochemica analysis and antimicrobial activity of Phytolacca dodecandra, Cucumis aculeatus and Erythrina excels. Int J biol chem sci 6: 692-704.

35. Anthoney Swamy T, Obey Jackie K, Miyogo Edwin O, Terer Erick (2015) In vitro antibacterial activity of the aqua extract of phytolacca dodecandra roots against laboratory strains of selected human pathogenic organisms. Int J Bioassays 4.

36. Saxena R, Patil P, Khan SS (2010) Screening for phytochemical analysis of Eucalyptus globulus Labill. and Emblica officinalis Gaertn. Nanobiotechnica Universale 1: 103-106

37. Ali HB, Blunden G (2003) Pharmacological and Toxicological Properties of Nigella sativa. Phytother Res 17: 299-305.

38. Obiorah S, Emmanuel E, Obiorah D, Orji N, Umedum C (2012) Phytochemical and antimicrobial studies on the extracts from leaves of Cajanus Cajan and Eucalyptus Globulus. International Conference on Environment, Chemistry and Biology IPCBEE V.49. 